\title{
Tools for Subversion: Illich and Žižek on Changing the World
}

Babette Babich

Fordham University, babich@fordham.edu

Follow this and additional works at: https://fordham.bepress.com/phil_babich

Part of the Continental Philosophy Commons, and the Ethics and Political Philosophy Commons

\section{Recommended Citation}

Babich, Babette, "Tools for Subversion: Illich and Žižek on Changing the World" (2017). Articles and Chapters in Academic Book Collections. 76.

https://fordham.bepress.com/phil_babich/76 


\title{
Tools for Subversion: Illich and Žižek on Changing the World
}

\author{
Babette Babich
}

\begin{abstract}
Reviewing the work of Ivan Illich, Robert Kurz and Stanley Aronowitz together with Heidegger's technically economic articulation of standing reserve correspondent to challenging forth (the world, ourselves, animals, plants, whatever), this essay takes up "the thought of the weak in search of alternatives" as Gianni Vattimo and Santiago Zabala argue for the possibility of interpretive transformation. In addition to Slavoj Žižek's analysis of the resistance to revolution that functions as corollary to the existential stress of the dislocated mind, this reflection includes a discussion of media and illusion in the digital realm of Baudrillard's 'integral reality.
\end{abstract}

To take the part of the weaker party in any community, society, exchange presupposes a hermeneutic. This hermeneutic is an interpretation of the world as those without power have access (or, more accurately said, do not have access) to the world: an interpretation of the vulnerable, of weakness, other than as defined from the position of those in power. But as Machiavelli as well as Hegel and Nietzsche remind us, those in power, from media to the arts to industry and government, any privilege at all, are constitutionally incapable of seeing anything apart from their own interests or perspectives-what Nietzsche called convictions and Gadamer called prejudices.

One can only stand up on behalf of others if one does more than merely advocate on their behalf. Advocacy, solidarity, organized intervention, all turn out to permit the continuation of exploitation, i.e., business as usual. For and like advocacy, intervention is its own reward-as Ivan Illich, the Vienna-born priest and scholar, spent a lifetime reminding us, ${ }^{1}$ this marvelously profitable truth of enterprise is that to

\footnotetext{
${ }^{1}$ See for a discussion of this phenomenon and Illich's battle against it, Chase Madar's retrospective account of Ivan Illich's attempts in 1968, speaking to the Conference on Interamerican Student Projects, to dissuade the deprecations of the colonialism of good intentions, Chase Madar's article: "The People's Priest," The American Conservative, February 1 (2010). Idealist imperialism lacks nuance and every one of Illich's diatribes assume a complex array of such nuances from his Deschooling Society (London: Marion Boyars Publishers Ltd., 2000) to his H2O and the Waters of

B. Babich $(\bowtie)$

Fordham University, New York, NY, USA

e-mail: babette.babich@gmail.com
} 
which humanitarian institutions owe their very corporate existence. One earns a respectable living by means of a career dedicated to rendering such "services," as Illich observed on site in the course of his life. Thus Illich's blunter point corresponds to a meditation on what is needed beyond speaking up for or even intervening on the part of others. When the gospel tells us that a righteous life is encapsulated in an impossible conjunction for the rich-sell all you have and come follow methis is way too much, and this is how Illich lived his life.

Advocacy, a life dedicated to public service, public philosophizing, the life of the humanitarian, corresponds to what Martin Heidegger criticized in his Being and Time as 'leaping in for' the other. ${ }^{2}$ In spite of professional philosophy's dedication to the common conviction that Heidegger had neither an ethics nor a political theory but just a reprobate politics, a claim compounded via his association with Nietzsche's "nihilism"- and almost everyone, even the otherwise perceptive Stanley Aronowitz argues this - it is Heidegger who reminds us of the ethical virtue of allowing - permitting-supporting the other's realization of his or her ownmost potentiality, by way of a freeing for such possibilities (only this liberation is letting be). Heidegger's comprehension of this solicitude is a Schopenhauerian radicalization of Kant's practical philosophy beyond the neminem laede [cause or make no one to suffer] that Schopenhauer is famous for. This exigence is the complicated compound that makes a maxim moral: "imo omnes, quantum potes, juva" [much rather help everyone as much as you can]. ${ }^{3}$ Thus, attention and forethought and consequentiality is presupposed for the sake of the other: one "does not so much leap in for the other as leap ahead of him.." By way of an essentially reticent regard for the other (in all the ways Illich likewise if differently emphasizes), such solicitude frees "the Other in his freedom for himself." "This same untimely tone echoes in Nietzsche's own reflections on Schopenhauer as Educator corresponding to Heidegger's reflections on what is required to come to know oneself [Sichkennenlernen].

Coming to oneself in this way for the sake of one's own freedom and freeing others for their own liberty are the traditional goals of education. And the juxtaposition of the interpretive project with praxis is the reason Karl Marx's dictum "Die Philosophen haben die Welt nur verschieden interpretiert, es kommt aber darauf an, sie zu verändern" would, in 1953, be inscribed on the walls of the Humboldt University in Berlin during the era of the DDR.

Forgetfulness: Reflections on the Historicity of Stuff (Dallas: Dallas Institute of Humanities \& Culture, 1985).

${ }^{2}$ Here Heidegger's contention is that such leaping in tends to "take way care from the Other and put itself in his position." Martin Heidegger, Being and Time, trans John Macquarrie and Edward Robinson (New York: Harper \& Row, 1962), 1.4, §26, p. 158 [SZ 122].

${ }^{3}$ Arthur Schopenhauer, On the Basis of Morality, trans. E. F. J. Payne (Providence: Berghahn Books, 1995), p. 144. I discuss Schopenhauer together with Illich in Babich, "Education and Exemplars: Learning to Doubt the Overman," in: Paul Fairfield, ed., Education, Dialogue and Hermeneutics (London: Continuum, 2011), pp. 125-149.

${ }^{4}$ Heidegger, Being and Time, pp. 158-159.

${ }^{5}$ Ibid., p. 159, [SZ 122]. See, for a discussion, Babich, "Solicitude: Heideggerian Care and Assistance" in: Paul Fairfield, ed., Relational Hermeneutics: Essays in Comparative Philosophy (London: Bloomsbury, 2018), forthcoming. 
That it was not removed in 1991 is fortuitous - it might well have been-and Gianni Vattimo and Santiago Zabala use this formula to frame their book, Hermeneutic Communism. ${ }^{6}$ For Marx, beyond "interpreting the world," what is essential is to change the world. The hermeneutic key remains just where Marx emphasizes in the second not-as-famous sentence as Vattimo and Zabala include this in their epigraph: "changing the world in the manner intended requires beforehand that thinking be changed...".

Here with respect to Vattimo's signal contribution to hermeneutics-namely 'weak thought,' il pensiero debole, "the full 'debolezza,' weakness" that "straight" thinking compels us to admit — we read that the "weak thought of hermeneutics becomes the thought of the weak in search of alternatives." If Vattimo and Zabala offer a sober analysis of who counts as the "weak" in the first half of their book, "Framed Democracy," pointing in particular to the "urban poor," it is in this connection that Illich remains exemplary. ${ }^{10}$ Like Dorothy Day-and professional idealists (i.e., humanitarians) are always embarrassed by such examples-Illich himself lived his life to the letter (and to the spirit of what Illich called "conspiracy" — con-spiratio) well beyond anything most clerics and certainly most academics preach. ${ }^{11}$ Yet the hermeneutic difficulty with Illich is the challenge of reading him. If reading Nietzsche, reading Marx, or Heidegger, includes the differently various challenges of grasping the range of their thinking, reading Illich includes an interpretive contextualization of his lived life-practice, not only serving the poor but challenging scholarship and public conceptions of education and health care ordered as both are ordered to the benefit of industry, and thus to the tradition of the heart. For Illich, this tradition was not a matter of interiority alone but works: 'to change the world' as Marx put it and for Illich (and for Marx) that means a life lived for others. In this way, in his way, Illich challenged sacred cows. And it is precisely for the sake of such challenges that we need hermeneutics: contra the dictates of analytic philosophy which only inscribes what it calls realist thinking (or what it calls 'critical thinking') as this corresponds to the received theory of whatever ruling class there happens to be, whether in society or the academy, which always reduces to the terms of conventionally institutionalized science. This will be by fiat, as the late Tzvetan Todorov has

\footnotetext{
${ }^{6}$ Gianni Vattimo and Santiago Zabala, Hermeneutic Communism: From Heidegger to Marx (New York: Columbia University Press, 2012).

${ }^{7}$ Karl Marx, epigraph to the Introduction to Vattimo and Zabala, Hermeneutic Communism, p. 1.

${ }^{8}$ Charles Taylor, "Modern Moral Rationalism," in Zabala, ed., Weakening Philosophy (Montreal: McGill University Press, 2007), p. 75; cited here from Vattimo and Zabala, Hermeneutic Communism, p. 97.

${ }^{9}$ Vattimo and Zabala, Hermeneutic Communism, p. 2.

${ }^{10}$ This 'exemplum vitae,' as Herwig Wolfram wrote as encomium to Illich's own teacher, as Illich praised Gerhardt Ladner for his own part, is key. See: Wolfram, "Gerhart B. Ladner (3 December 1905-21 September 1993)," Proceedings of the American Philosophical Society, Vol. 139, No. 4 (Dec., 1995): 440-442.

${ }^{11}$ See for a discussion of some of the complex issues that have led to this neglect, Babich, "Spirit and Grace, Letters and Voice or Performance Practice and Alchemy in Alan Rickman and Nietzsche," Journal of the Philosophy of Education, Vol 3, 2018, Forthcoming.
} 
observed, of the totalizing scientism of what is said to be modern rationality, that is: all the 'truth' you need. Zabala and Vattimo read the same compact in the other direction, as they analyse the uncanny political collusion inscribed into analytic philosophy between George Bush and John Searle, as a "winner's history" that also happens to haunt the infamous denunciation of Jacques Derrida—and every related kind of continental philosophy — on the part of Barry Smith and friends whose prejudices led them to condemn the lifework of a colleague in order to judge and so to dismiss Derrida's writing as "either trivial or false." 12 The "winner's history" in philosophy is analytic philosophy which seeks, as Vattimo and Zabala argue that Searle seeks, to dissolve "philosophy into the sciences," discarding "everything that does not submit to the Western rationalistic tradition, including different philosophies." ${ }^{13}$ This includes philosophies expressed in other languages and as Vattimo and Zabala quote Derrida, the "imperialistic approach" of analytic philosophy ensures-and this success is now almost utterly complete in Europe as it has been in Anglophone countries for decades - that "no literary work, no philosophical work can receive worldwide legitimation without crossing the [United] States, without first being legitimized in the states." ${ }^{14}$ It is not tradition that gives the US this power in the academy but the "winner's history," a glamour maintained in spite of its ongoing bankruptcy.

Like Vattimo and Zabala, Illich challenges our faith in what we call democracy. In addition, and like his hermeneutic critique of the realist rationalism characterizing, mainstream or institutional philosophy, Illich also challenges our faith not in the churches, as if we believed in these, but where our faith is found today: in science and modern medicine but and especially in times of economic stress, our faith in education. ${ }^{15}$ Arguably, Illich's most subversive claim would be his argument that education instructs its subjects in the rules of acquisitiveness and the value of the objects of the same.

Although Illich's critics protest, it is not as if anyone really disagrees. To the contrary: we take just this successful acquisition to be culture and our students ask only how they might obtain such an efficacious education. It is only the failure of education to deliver such acquisitive efficacy that concerns us.

More and more, students the world over look upon the university as a means to an end, to getting a job and students believe this all the more as they advance along the academic ladder. Universities are themselves complicit and undergraduate education is 'marketed' not as a 'liberal' pursuit (pace Michael Oakeshott and Cardinal Newman and, before the medieval institution of the university, pace Plato and Aristotle) but, just as Illich argued, access to a 'job,' which access in turn yields the very same material goods of a material culture that for Illich is increasingly inscribed as the real subtext of school. In a different voice, with all the sobriety of a social

\footnotetext{
${ }^{12}$ Vattimo and Zabala, Hermeneutic Communism, p. 36.

${ }^{13}$ Ibid., p. 37.

${ }^{14}$ Ibid., pp. 35-36.

${ }^{15}$ I refer here to Illich's De-Schooling Society, not (as it was misunderstood) as a brief against learning but against the institution and to the extent that most schooling is a sham and pretended education, as both Nietzsche and Kant (albeit in the good Lutheran service of Caesar), in his $A n$ Answer to the Question, What is Enlightenment? have observed.
} 
scientist, albeit without reference to either hermeneutics or Illich, Stanley Aronowitz points to similar issues concerning the profit-motives of university education and its proliferation of increasingly meaningless certificates not just in terms of relevance for a job, even at the university, but also now in practice, with all the contradictions capitalism ensures. ${ }^{16}$ "Hope," as Aronowitz writes,

has become an entailment of 'career,' an invitation for some to make it, even in the midst of the joblessness that is now a chronic feature of a system no longer able to accommodate even its best and brightest, let alone the millions suffering drastic economic decline. ${ }^{17}$

In our day, the professionalization - that always means the cooption-of the scholar regarding what Max Weber once innocently called a vocation in his own polemic against the careerism that is the constant soul-disease among scholars-it is a disease that has been with us, so Plato tells us, so Marcus Aurelius tells us, for the lifetime of the written word-could not be more consummate.

And who today seeks a PhD for its own sake and not also and much more for the job prospects it is thought to afford (and increasingly argued to afford) by right?

If Illich can remind us that the university was once a place dedicated not to the care of the self, as Foucault has made it popular to speak of the self, but and rather of the soul in his study of study, In the Vineyard of the Text, ${ }^{18}$ it is also the case that the university has not been such for a long time as Nietzsche also reflected writing on Schopenhauer and in his earlier, rarely read, and very complicated dialogue $O n$ the Future of Our Educational Institutions. In our times, and apart from Illich, only Jacques Ellul and Günther Anders have been as consistent in their criticisms of this perniciously vapid circle.

The academy remains a business in service of capitalism.

And this is true in practice, with bells on and with an eager vengeance (digital humanities anyone, asks the young scholar who thereby insists upon a diligent uprooting of the old - who needs books? - and the installation of him- or herself in the place of the old guard). That the parenthetical point has always been the story of things is neither important nor particularly accurate. Let us hear Marx again: "Philosophers have only interpreted the world in various ways, what matters, however, is to change it."

The importance of hermeneutics via Illich and Heidegger (and Nietzsche and thence to Kant and Schopenhauer) and here by way of Vattimo and Zabala, is its practical dimension, this is what can be world changing about it, that is, once articulated on behalf of the weaker portion of society, namely for those without power and hence without the influence to assert their own perspective contra the imposition of the views and the rule and because this is the only reason for rule, the domination

\footnotetext{
${ }^{16}$ For one of the most timely — and insightful discussions available today—analyzing political economics in the global context but with specific sociological and historical reference to the US, see Stanley Aronowitz, both sociologically and historically, "The Winter of Our Discontent," Situations: Project of the Radical Imagination, Vol. IV, No. II (2012): 37-76.

${ }^{17}$ Aronowitz, "The Winter of Our Discontent," pp. 67-68.

${ }^{18}$ See Ivan Illich, In the Vineyard of the Text (Chicago: University of Chicago Press, 1993) for a range of references to (and in the very constellation of the footnotes which are the real reason for this text, as a commentary upon) a number of different editions of the Didascalicon.
} 
(or oppression or exploitation) of others. This is the intriguingly clear inception for and point of Vattimo's and Zabala's Hermeneutic Communism. Here it matters to the letter that the hermeneutic approach is not the dominant approach-it is the heart of the kind of 'continental' philosophy that is refused by mainstream or analytic philosophy—nor does it have recourse to that same authority in the university. ${ }^{19}$

What hermeneutic philosophy does is to take the part of the other, making it one's own part all the while without forgetting the otherness of the other. Thus Gadamer argues that understanding is always understanding otherwise - that is, as we can say today, 'queered against' ${ }^{20}$ or contra what one had taken oneself to understand, both in the past, and because this is the way prejudice works, in advance. The point of hermeneutics is to be open to just such otherness. Understanding, to be understanding, is always an understanding otherwise than the suppositions or prejudice that one begins by taking for granted. Between Heidegger's reading of Husserl, which was more of an indoctrination, and Heidegger's reading of Nietzsche, which was a liberation (though like his own teacher Schopenhauer, it always turns out that Nietzsche is more of liberator than most of us are able to bear), Heidegger's hermeneutic questioning is a not-already-knowing reflection on our own already-knowing, our prejudices, our natural attitudes, again: what Nietzsche called our "convictions." And such a reflection, if we follow it through-without clinging to our selfsubscribed bondage, i.e., to the restraints that were for Kant the "guiding yoke [Leitbande] of the great unthinking masses"-corresponds to what Kant called enlightenment and what Nietzsche and Marx both called liberation.

\section{The Eternal Return of Capitalism: The History of Illusion}

Robert Kurz, the late Marxist and critical theorist of the left, was fond, as a Marxist political economist ought to be fond, of the image of eternal recurrence. For as Kurz pointed out, the thing about capitalism, again and again, is that nothing seems to faze it. ${ }^{21}$ In other words, the contradictions of capital are confirmed constantly and capitalism fails, again and again. And yet, and this is the eternal return that intrigued

\footnotetext{
${ }^{19}$ I discuss this in some detail in an interview with students regarding publishing and - not incidentally_intellectual capital in Babich, "An Impoverishment of Philosophy." In: Dennis Erwin and Matt Story, eds., Purlieu: Philosophy and the University (2011): 37-71 and more generically in terms of the continental divide here: "On the Analytic-Continental Divide in Philosophy: Nietzsche's Lying Truth, Heidegger's Speaking Language, and Philosophy," in C. G. Prado, ed., A House Divided: Comparing Analytic and Continental Philosophy (Amherst, NY: Humanity Books, 2003), pp. 63-103. For a recent discussion, see "The Last of the Continental Philosophers," the first installment of a four- (and ultimately eight-) part dialogue initiated by the game designer and 'outside' philosopher, Chris Bateman, published online at the end of 2016 and the beginning of 2017 on Bateman's usually gaming themed blog: Only a Game: http://onlyagame.typepad.com/ only_a_game/2016/11/babich-and-bateman-1.html

${ }^{20}$ I discuss this complex convention, popular at the moment as it draws for its metonymic capital on queer theory in Babich, The Hallelujah Effect: Reflections on Music, Performance Practice and Technology (London: Routledge, 2016 [2013]).

${ }^{21}$ Robert Kurz, Vie et mort du capitalisme (Paris: by Editions Lignes, 2011). See too Kurz, ,Kapital und Geschichte" in Neues Deutschland on April, 24, 2009, p. 6.
} 
Kurz, we always prop it up - as if we cannot bear even the idea that our most beloved economic system (we call capitalism 'democratic' as if this could be 'true' or as if this were the point of capitalism which is all about gaining economic advantage via the disenfranchisement of others) might be inherently defective. To avoid this suspicion we perpetuate it even in its refutation, throwing good tax (and that means public) funds after bad private losses, which of course (as commentators observe only to be instantly ignored) amounts to a transfer of common resources, funneling public wealth, into the hands of a few. What commentators do say that is repeated in the media (as if it were or could be 'true') is that these few-always described, in an irony that would not have surprised Marx, as 'job creators' - may be expected to give back to the community in spades. When the same 'jobs' are not forthcoming, i.e., when wage slaves are denied the opportunity to be such (this is the meaning of joblessness), commentators argue that the problem is that insufficient public funds were made available for the purpose whereby, as the logic of imperialistic reason holds, the only solution is to transfer more public funds to private fortunes. And so we do.

It is in this same spirit of eternal survivability or recurrence, that Kurz reprises his own argument on the collapse of capitalism followed by the eternal return of the same, in his study of the 'collapse of modernity'22:

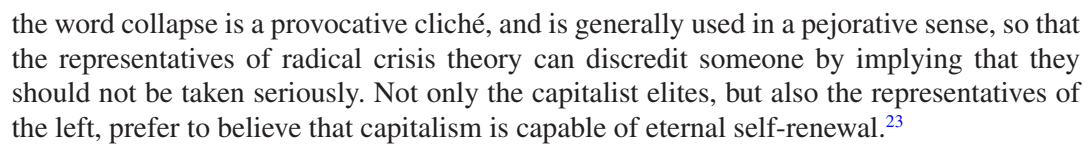

Like the 'terminator' of popular film culture, our governments do for capitalism what Hollywood's culture industry has always done for the generic action hero, like Arnold Schwarzenegger (and in his post-gubernatorial phase he has never needed its ministrations more). Capitalism continues to rise from its ashes, so we are persuaded, not a little because of the bewitching power of its totalizing force, in spite of every disappointment of the same such as the world economic crises of 2006-2007-2008 (oh, pick a year as these are ongoing) together with a resolute exclusion of any and all alternatives. Once again: the only solution is to transfer more public funds to private fortunes. This permeates every level from the system of money - the We must save the banks! brigade - to technology.

Kurz was also consistent in his Marxism, and this is an important insight beyond the doubtless valid critiques that emerge from conspiracy theories, as he also denied the privileged class. Analysing the subject of the modern world, Kurz discernsrather as one learns that a sexual offender was himself the victim in his turn of

\footnotetext{
${ }^{22}$ See, for example, Kurz's Der Kollaps der Modernisierung (Leipzig: Reclam, 1994 [1991]) as well as his Schwarzbuch Kapitalismus. Ein Abgesang auf die Marktwirtschaft (Eichborn: Ullstein Taschenbuch, 2009 [1990]) in which he makes the simple empirical observation that the impoverishment is the effect of the market economy: „Marktwirtschaft macht arm."See too his Weltordnungskrieg: Das Ende der Souveränität und die Wandlungen des Imperialismus im Zeitalter der Globalisierung (Berlin: Horlemann, 2003).

${ }^{23}$ Kurz in a 2009 interview with IHU online. http://libcom.org/library/2009-interview-ihuonline-robert-kurz.
} 
abuse, in a ring that is a ring in a chain of similarly ringed abuses, in the unconscious mechanism of the eternal perpetuation of the same violence, as Foucault and Lacan and Sade argue that the erotic apparently cannot do without oppression and violation-that all those so-called capitalist rulers, the "winners," are themselves only illusions. Like the masters in Fritz Lang's Metropolis, they live in a fantasy world, inside the gilded cage, a world the workers in the iron grip of the Moloch below can only dream about. Kurz's point, Marx's point, is that both images are correspondent, i.e., reciprocal, phantoms. ${ }^{24}$

What matters is the real-and that collapses or vaporizes constantly.

Slavoj Žižek is one of the few critics to be consistently honest in the face of contemporary academic critique. Thus Žižek in November of 2012 highlighted what should be seen as a political paradox, however one regards it, from any historicoeconomic perspective, left or right:

The primary political effect of the economic crisis was not the rise of the radical left, but of racist populism, more wars, more poverty in the poorest Third World countries, and widening divisions between rich and poor. ${ }^{25}$

The problem for critical theorists from Habermas to Honneth and nearly everyone on the so-called left, is that they seem unable to overcome the legacy of Marxist materialism-when they are not (qua academics, and see the allusion to Illich above) in complete complicity with the liberal fantasy of popular media (whereby everyone fairly well agrees with whatever theme appears on the op-ed page of the New York Times, as if the Times itself were not an instrument of imperialist doctrine or else one concurs with whatever a given network television broadcaster says) ${ }^{26}$ But like the not-too well-known Günther Anders ${ }^{27}$ and to a lesser extent, like Adorno, Žižek manages to continue to speak truth, reminding us, as Vattimo and Zabala also do with their own reference to "framed democracy," that democracy itself is a phantasm (with all the gleam and shine of the imaginary), emphasizing what Nietzsche would have called the ultimate issue, and going so far as to reflect as Žižek does, in an unattributed echo of the late Jean Baudrillard, that it almost

\footnotetext{
${ }^{24}$ See for a discussion, Babich, „,Geworfenheit und prometheische Scham im Zeitalter der transhumanen Kybernetik Technik und Machenschaft bei Martin Heidegger, Fritz Lang und Günther Anders"in: Christoph Streckhardt, ed., Die Neugier des Glücklichen (Weimar: Bauhaus Universitätsverlag, 2012), pp. 63-91.

${ }^{25}$ Slavoj Žižek, “Capitalism: How the Left Lost the Argument,” Foreign Policy, November 2012.

${ }^{26}$ This would include Charlie Rose, if I exclude Bill Moyers because he manages to be different, and because this is a gift of the spirit not the intellect (although intellectually, Moyers is shoulders above the stature of his otherwise stylistically elegant colleague).

${ }^{27}$ Günther Anders, a student of Husserl and Heidegger and Tillich, a friend to Gershom Scholem and the first husband of Hannah Arendt, as well as being a junior colleague and erstwhile student of Theodor W. Adorno was born in 1902 and died in 1992 - a decade shy of my own teacher Gadamer's length of life, 1900-2002. What was rare about Anders was the constellation of his interests in technology and politics and philosophy and activism, where the last sets him apart from others who shared his interest.
} 
seems "as if this crisis were staged to demonstrate that the only solution to a failure of capitalism is more capitalism.". ${ }^{28}$

If the problem for critical theory in its current instaurations is its utter lack of critique, what makes Adorno continually interesting is that unlike Habermas, he managed (and it is an achievement) to remain susceptible to Nietzsche's persistent contagions and the range of his complexities. If Adorno is not a key interlocutor for Vattimo and Zabala, openness to Nietzsche is manifest throughout their text and this is indispensable as it is a prerequisite for the openness to any critique that would be able to be counted as such today. This hermeneutic critique of a Heideggerian and Nietzschean kind is a self-critical reflection. Thus Vattimo's and Zabala's Hermeneutic Communism: From Heidegger to Marx can be set together with Žižek's remark that "Reading Heidegger against the grain, one discovers a thinker who was, at some points, strangely close to communism." ${ }^{29}$ Of course Žižek-but this is his strength-overstates the matter. At the same time-but this is Žižek's trademark - he understates as well. One does not need to read Heidegger against the grain: Heidegger's reflections in his Letter on Humanism but also the reflections that are key to the technology lectures he gives to the Club of Bremen, that is to German business leaders in the post-war period of German re-building and development, are patently communist (without using the term as such). Hence when Heidegger defines modern technology as a 'challenging forth,' he defines such challenging in economic terms, whereby it

is always itself directed from the beginning toward furthering something else, i.e., toward driving on to the maximum yield at the minimum expense. The coal that has been hauled out in some mining district has not been supplied in order that it may simply be present somewhere or other. It is stockpiled. ${ }^{30}$

Nature becomes a stock of natural resources, as does the human being. If we miss the economic, "strangely close to communism" undertone of Heidegger's writings on technology — and most readers do-we find ourselves reading a romantic reactionary. And that is far safer, but Heidegger makes it fairly clear that the human being is increasingly ordered as part of the same "standing-reserve." As he says (and the sentence bears analysis) "The current talk about human resources, about the supply of patients for a clinic, gives evidence of this." 31 The issue here concerns the hermeneutic of human resources - resources for what? The "supply of patients for a clinic"? What determines the benefit? The patients-shades of the current US Healthcare plan which is designed to require citizens, rather than employers, to use their own personal resources to obtain various levels of insurance-or the clinic?

What finds different expression in Adorno and Horkheimer's Dialectic of Enlightenment is also underscored in terms of industry where Heidegger explains the difference between what looks the same to our eyes, namely today's forester in

\footnotetext{
${ }^{28}$ Žižek, "Capitalism."

${ }^{29}$ See on this the preface to Žižek's Less Than Nothing.

${ }^{30}$ Heidegger, The Question Concerning Technology, p. 15. My emphasis here.

${ }^{31}$ Ibid., p. 18
} 
the service of forestry and the old-fashioned or traditional woodman. The difference for Heidegger is that today's forester is

commanded by profit-making in the lumber industry, whether he knows it or not. He is made subordinate to the orderability of cellulose, which for its part is challenged forth by the need for paper, which is then delivered to newspapers and illustrated magazines. The latter, in their turn, set public opinion to swallowing what is printed, so that a set configuration of opinion becomes available on demand. ${ }^{32}$

We need Horkheimer and Adorno, as indeed Illich and Baudrillard to begin to unpack the connections Heidegger suggests here.

If I noted above that the problem for today's critical theory is its utter lack of critique, the problem of communist and Marxist theory tends to be its commitment to historical materialism. This commitment does not derive solely from the letter of the Marxist text and certain influential accounts of the same but it is the danger of automatic, rationalistic, systems-technological thinking that includes almost all leftists and that includes Marxists of an academic and that means Hegelian stripe, a striping that included Kurz as it also included (weakened in Vattimo's sense by Nietzsche) Adorno and Anders as well as Žižek. This danger remains abandoned to the materialist expectation of the ghost of Hegel that expects that the world spirit should turn its eyes, Lyncaeus like, so very utterly inward, that and of itself, the entire fabric of civilization reverses upon itself and comes out through one or another orifice as an already accomplished Marxian conversion.

The revolution is coming and change, like the second coming, in fact exactly like the second coming, comes about of itself, given sufficient consciousness, that is: faith.

If materialism is the problem, one needs a Nietzsche to come and tease Marxism about the sense in which it, too, is still pious - and here there is the Christological secret of Hegelianism - the rest of what is at stake stands, and falls, with the contradiction this entails for practice. If the most seductive theory of the market economy is Calvinistic to this day, predestination (this code is inscribed in the financial maxim: too big to fail), the expectation that the revolution will come, when it comes, this same quietism is the curse of Marxism, of itself, by itself. But every reading that looks to both Nietzsche and Marx shatters on the ground of Hegel.

In the same fashion, the weakness of the Marxist focus on science is that it remains uncritically scientistic. Thus my friend, the late Paul Thomas, the Berkeley political theorist, took only part of this point as I tried to explain it to him regarding scientism in his recent study of Engels, nicely thanking me, as he did, while nevertheless proceeding to return, virtually immediately to the standard materialist account. ${ }^{33}$

Intriguingly, the same automatism is ascribed to capital. Thus we might remember Kurz once again: Where Nietzsche's eternal return of the same, in an infinite permutation of energies in a closed system, is over-determined, eternally so, what intrigues Kurz is the notion of repetition as it differs in the real world and in our

\footnotetext{
${ }^{32}$ Ibid.

${ }^{33}$ See for this study, more timely than ever, Paul Thomas, Marxism and Scientific Socialism: From Engels to Althusser (London: Routledge, 2008).
} 
prejudices or convictions regarding what can and cannot be done in the world of political economics and that means in spite of any material determination as it would seem to be formed of smoke and mirrors, such that capitalism is again and again reborn out of its own ashes to use Kurz's metaphor. ${ }^{34}$ Or at least out of the ashes of whatever remains for yet another bailout.

Advancing Kurtz's analysis of collapse and persistence in late capitalism and industrial society in our real world, post the late 1980s and early 1990s, and again, post the last years of the first decade of this new century, today, here and now, the Brazilian critical theorist, Fabio Akcelrud Durão, points out that for Kurz, "the potential for change, what is other, has to be sought inside the system of exchange." 35 Durão argues that just where a kind of conceptually bad faith, that is: irony, an akrasia of critique as it were, can be said to characterize the West, things are different in Western-cum-non-Western countries like his own:

\begin{abstract}
Whereas in advanced capitalist countries, those inside the market have to try to pretend they are not, in Brazil, those outside it represent perfect capitalist subjectivities. Precisely because they suffer need in a society that fully eradicated pre-capitalist structures of life, they completely believe the promises made by that which they do not have. The expensive car really brings beautiful women; the cigarette really takes one to the old West. In the closed totality of central capitalist countries, "there is no place anymore outside the machinery, from which one may name the phantasmagoria" for "only on its own incoherence should the lever be set" 36
\end{abstract}

It may turn out that Illich is more helpful here. Durão argues that there is a possibility of revolution precisely to the extent that such subjects are able to demand "that commodities be equal to what they communicate about themselves," and that one has thereby nothing less than a "practice of immanent critique.". 37

To explain this circumstance, Durão invokes Kurz's convention to describe the people of Brazil, as "monetary subjects without money" and Aronowitz makes a similar point paraphrasing A.J. Liebling, in the context of his own analysis of the ideological sediment embedded (this is also hermeneutics) in descriptions of "the contemporary capitalist system in terms of the "free' market," reflecting-here comes the paraphrase - that "the market is [only] free for those who own one." ${ }^{38}$ Yet Kurz's 'monetary subject without money' happens to describe most people in the United States: not only does the same fantasy laden, subjective deficit-inscription into capital correspond to the so-called $99 \%$ but it is the very reason for credit, which, perversely, means debt. The vast majority of homeowners in the United States do not 'own' their own homes, but the bank does. Indeed nothing better illustrates Kurz's observation that the market economy "makes" one "poor" than the

\footnotetext{
${ }^{34}$ Kurz, "Die Himmelfahrt des Geldes. Strukturelle Schranken der Kapitalverwertung, Kasinokapitalismus und globale Finanzkrise," Krisis 16/17 (1995): 21-76.

${ }^{35}$ Kurz, "Spät Kapitalismus oder Industriegesellschaft?", p. 369, cited in Fabio Akcelrud Durão,

"Adorno in Brazil," Revista Atenea, pp. 9-24, p.19.

${ }^{36}$ Durão, "Adorno in Brazil," Revista Atenea, pp. 18-19.

${ }^{37}$ Durão, "Adorno in Brazil," p. 19.

${ }^{38}$ Aronowitz, "The Winter of Our Discontent,"p. 45.
} 
housing bubble. Kurz's insight is all the more devastatingly true to the economy of "upside-down" houses as they are called, i.e., where the 'market value' of the house is worth less than the value of the same for the bank (that would be the mortgage and that entitled debt is immune to market changes) that means-talk about making poor - that whatever value remains to be paid on the mortgage, a future and secured and unchanging value to the bank, must always be calculated in addition to the already acquired and thus already very liquid asset of the down payment already taken by the bank to secure the same mortgage. What goes up in smoke, 'making one quite literally poor,' i.e., as if one had been robbed, is not simply the language game of devalued values, here that would be devalued house prices, but real cash savings, be it from wage income, or any other labor value all nicely congealed for the capitalist in fungible cash and traded in for nothing less than the human hope for life-security: for a place to live, and hence for a mortgage to be owed on a subsequently, all-too- conveniently for the bank, devalued house (the array of banker's schemes to take this as a loss boggles the mind, such are the arrays of double and triple book-keeping, including insurance payments and tax write-offs-N.B., not tax-credits, that's for the little people-on top of all the government bailouts) at interest rates that and in order to have been afforded as such, at the then time, often are tied to a future scheme such that they subsequently increase just as the house value decreases. It is a capitalist wet-dream, a scenario to warm a speculator's heart and it is the only game in town, because in America and across the globe, political reforms shore up the capitalist rather than the end-consumer or citizen.

And, speaking of banks, as Žižek asks in his (and the title should now begin to seem ironic), Less than Nothing

But why did we have to give billions of dollars to the banks in 2008 and 2009? Because, without a functioning banking system, the entire (capitalist) economy collapses. Banks should thus also count as privatized commons: insofar as private banks control the flow of investments and thus represent, for individual companies, the universal dimension of social capital, their profit is really a rent we pay for their role as universal mediator. This is why state or other forms of social control over banks and collective capital in general (like pension funds) are crucial in taking a first step towards the social control of commons. ${ }^{39}$

Žižek is able, because of the theoretical and socio-cultural position he occupies to both frame the objection to his point and its counter in a nicely compound sentence of the kind those who cannot read English are fond of using as index of obscurity:

Apropos the reproach that such control is economically inefficient, we should recall not only those cases in which such control was very effective (this was, for example, how Malaysia avoided crisis in the late 1990s), but also the obvious fact that the 2008 financial crisis was triggered precisely by the failure of the banking system. ${ }^{40}$

I think it is crucial to repeat Žižek's last point here just because this empirical detail manages not to be noted by economists left and right: "the 2008 financial crisis was triggered precisely by the failure of the banking system.". ${ }^{41}$

\footnotetext{
${ }^{39}$ Žižek, Less Than Nothing: Hegel and the Shadow of Dialectical Materialism (London: Verso, 2012) p. 184.

${ }^{40}$ Ibid.

${ }^{41}$ Ibid.
} 
We are talking about a collective trauma.

A separate point has to do with the real dynamic of the eternal that is the eternal recurrence of the capitalist same-old, same-old as we saw that Kurz analyses this. In the words of (the then-critical theorist) Gerry Stahl, writing in 1975:

Social reform is objectively impossible under advanced capitalist society. The contradictions of capitalism do not make reformation easier, rather, they infect any attempts at change, distorting and strangling them. ${ }^{42}$

The mechanism, the consolidation of power on the part not of the weaker but on the part of those with power, is unchanged. There is bribery in congress. We call it lobbying. There are stolen elections due to outright fraud and on all levels beginning with the presidency of the United States down to every municipality, and we regard such fraud as a technical problem about which (this is the political travesty of Gore vs. Bush, Sanders vs. Clinton) there is nothing to be done (where is Beckett in our times?). To be sure, the beauty of election fraud, like banking fraud in the digital age is that there is exactly no proof because there can be none-and increasingly the same digital malleability, one way or the other, in the future but especially with respect to the history, will be true at every level.

There are ways to burn books without fire. ${ }^{43}$

We fight undeclared wars and now and increasingly by means of drones, engage in combat action at a distance, which we call surgical, and we are poised to include domestic targets, any targets, anywhere. The earth is raped in more thoroughgoing ways than ever before, whole species, not just rare ones but common species: whales, wolves, lions are vanishing everywhere, not in some future, but now: in our years, at this time. We take notice of none of this because, and this is Žižek's point in his recurrent reference to the Chinese joke, the curse of living in interesting times: the violent gap between rich and poor means that, increasingly, life as we know it changes - and who can pay attention to anything but the immediate? Send someone through airline security and have that person dismantle their belongings for security examination via machine and have that person disrobe, and in the US, but not elsewhere, you remove your shoes, and submit to the intimate inspection of your body, either via physical groping, or virtually by means of radiation that you are told is harmless despite the fact that such an assurance, to be likely, would have required testing over the last 15 or 20 years to accumulate data on its effects on human bodies. No one can know this but we are told that because there is no proof of harm, it is certainly safe. Who pays attention to anything? One is thankful that it is not worse and one is grateful if one manages to remember one's personal property because as public announcement intone, passengers routinely forget their iPads, iPhones, laptops - all the high-end signifiers of consumer desire.

\footnotetext{
${ }^{42}$ Gerry Stahl, Marxian Hermeneutics and Heideggerian Social Theory: Interpreting and Transforming Our World (Purdue, 1975. Ph.D., Diss). Stahl himself has gone on to a career at the high academic level in information theory and computer science.

${ }^{43}$ But this would have been Baudrillard's point about integral reality, virtuality, everything we call media now in order to forget the vacuity, volatility of the medium, not that we heard him then, nor do we hear him now.
} 
Our students have no jobs-hence there was reason to note Illich's critique of school above. At the same time what pensions we have are gutted, our own savings lost, our own houses likewise, as well as those of friends and colleagues, are 'downsized,' which is a way of saying that they too have no jobs, entire nation economies collapse. And those with jobs, those who saved their houses, those whose friends are employed, shutter their perception, like airline passengers processed through security.

In the interim, the powers of collective suppression are only intensified, only increased. There is no Occupy Wall Street movement as I write, not even the peripheral tiny band that for some time early in the Fall of 2012 gathered off and on to protest Goldman Sachs on the southern corner of Central Park West, near Merchant's Gate and just across from the Trump International Hotel and Tower, with its silver globe fetish to Trump's original Queens and built to satisfy the anxieties of the people who paid for the towers - not Trump but Hong Kong financiers, who needed something round and something shiny to deflect sha, poison arrows: a feng shui "cure." In his elegantly comprehensive, "The Winter of Our Discontent," Aronowitz points out just how quickly things went in the 'American Fall' that was Occupy Wall Street:

By November a coordinated effort by 18 big city mayors from both main political parties had forced the occupiers to disband sometimes by violence, except in a few cities such as Los Angeles and Philadelphia where the local political establishment feared a blowback. ${ }^{44}$

And in the same interim, in the spring of the following year, a similarly coordinated effort also kept news of student protests in Montreal, Canada (red square, here referring to a red patch) from university scholars in New York (that would be Buffalo as much as New York City) for-this is how the digital, this is how the media controls the real-what's not on the news, not on the internet, does not exist. ${ }^{45}$ There are ways to burn books without fire. Just call it fake news and have done with it.

There is no revolution, if it does not change the world. As Alasdair MacIntyre points out, as political theorist after political theorist has pointed out, all of them willy-nilly following Marx, following Rousseau, a revolution just to be a revolution has to succeed (and political 'theorists' are characterized as such because they argue for the distinctions, the characteristics of a successful revolution). Here, as MacIntyre saw, there is much to learn from the philosophy of science, from Paul Feyerabend to Thomas Kuhn: not only does 'anything go' but the existing paradigm always functions to dismantle revolutionary thinking before it begins. This is as true in philosophy — this is the meaning of analytic philosophy — as it is in the ordinary, real world.

In Žižek's exposition, once again, what bears reflection is the practical contest between theory and practice, and now we are back to the housing bubble, the economy, the TSA:

\footnotetext{
${ }^{44}$ Aronowitz, "The Winter of Our Discontent,"p. 40.

${ }^{45}$ See the contributions to the website http://publicuniversity.org.uk/2012/06/05/the-crisis-of-thered-square/ entitled, Campaign for the Public University, owing to the efforts of Mark Carrigan, a graduate student, at the time, and then-and-still a twitter colleague in sociology at Warwick, and not less to Tracy Strong, who translated the texts from French into English.
} 
For all that crises shatter people out of their complacency and make them question the fundamentals of their lives, the first spontaneous reaction is not revolution but panic, which leads to a return to basics: food and shelter. The core premises of the ruling ideology are not put into doubt. They are even more violently asserted. ${ }^{46}$

Thus Žižek can title his essay "Capitalism: How the Left Lost the Argument" and we have already cited his concluding non-conspiratorial because merely empirical contention:

It is almost as if this crisis were staged to demonstrate that the only solution to a failure of capitalism is more capitalism. ${ }^{47}$

None of this functions, nor does Žižek claim that it functions, as a refutation of Marxism. Much rather the mechanism Žižek outlines works as it does because the intrinsic working of capitalism includes, this is its logic, thank you Hegel, the mechanism of co-option which does not and never did oppose reformation but (and this is so much more effective) simply absorbs reformation.

The example of environmental or green capitalism is perhaps best on a point Žižek and Naomi Klein make (both to be sure and in different ways more dramatically than most $)^{48}$ but which is also the stock of most responsible discussions of sustainable development (hint, Maurice Strong will not be the lead to follow here). Sustainable development is always underdevelopment by other means and with a smokingly good conscience. ${ }^{49}$

Thus Kurz argues that

The attempted reform is transformed under the commodity form of relations. The relation of the conscious reformers to their intended reform is obscured and takes on the apparent form of a relation of "the owners of capital" to a reform which has been altered to serve their interests. The apparent benefactors of the distorted reform need not be identifiable, they need not exist as individual people. The reform has simply been made to serve the criteria of exchange value or capital and the human agents presumed to be behind this fetish are invisible, autonomous, abstract, indefinable: the System, the Man, the They, the Power Elite. ${ }^{50}$

Notice the distortion of reform and note too that this now and still-today institutionalized distortion took a Marcuse to theorize in the complex chaos of supposed freedom and factive unfreedom that is still the United States but increasingly encompasses the world, although the lineaments of this analysis are already to be found in Horkheimer and Adorno, and perhaps most chillingly in Anders. ${ }^{51}$ At the

\footnotetext{
${ }^{46} \mathrm{Ibid}$. Simon Winlow and Steve Hall repeat this assessment, with different fire, in their account of the 2011 summer riots in the UK. See Winlow and Hall, "A Predictably Obedient Riot: Postpolitics, Consumer Culture, and the English Riots of 2011," Cultural Politics, 8/3 (2012): 465-488;

${ }^{47}$ Žižek, "Capitalism: How the Left Lost the Argument."

${ }^{48}$ See, once again, Žižek, "Capitalism: How the Left Lost the Argument" (among other earlier variations here) and Naomi Klein, The Shock Doctrine: The Rise of Disaster Capitalism (New York: Picador, 2008).

${ }^{49}$ See on this the range of reflections in Aidan Davison, Technology \& the Contested Meaning of Sustainability (Albany: State University of New York Press, 2001).

${ }^{50}$ Stahl, Marxian Hermeneutics and Heideggerian Social Theory, p. 95.

${ }^{51}$ See Babich, "On Machines as the Masters of Humanity: Martin Heidegger, Günther Anders, and the Singularity of Digital Technology," Journal of the Hannah Arendt Center for Politics and Humanities at Bard College, 2 (2012): 122-144.
} 
same time this analysis also requires a hermeneutic reading, and thereby a connection with Heidegger and for its own part exemplifies Gadamer's account of the hermeneutic historicity of leading scholars' readings, and what they bind-which secured account thus preserves a 'life' in the academy-and what they loosewhich is correspondingly silenced. All this is part of politics, if only the bootless (and usually gutless) politics of the academy.

One point to be added here in conclusion, from Durão and from Kurz, suggesting in an underwhelmingly globalized fashion, that (I say this quite apart from the unimaginable dimension of the race question in Brazil) that we are all Brazilians, pace Durão, to the extent that we are all mythic thinkers (and the colonialist conviction that 'whites' do not think in the same mythic fashion is part of the race problem).

We believe at a far deeper level than we consciously suppose ourselves to believe in what is advertised and we do so almost without remainder. This is the power of market priming, ${ }^{52}$ as this is embraced today in all fields from the arts to the academy (call it branding). Thus Robert Hullot-Kentor ${ }^{53}$ has pointed to the need to distinguish between the equivocal senses of the term 'culture industry' corresponding to the culture industry (all around us) and Adorno's (and Horkheimer's) culture industry, which in Durão's recapitulation of this distinction is "itself part of the process that hinders the perception of the primitivization of society that the Frankfurt thinkers wanted to present.".54

But US consumers deeply believe, as Durão tells us the numerous dispossessed (or better or more accurately said never-once-possessed) Brazilian believes, in "the promises made by that which they do not have." 55 This drives the acquisition of every new smart phone (and buyer's remorse is hard on every such purchase). The difference in the more literal faith is the very possibility of subversion, as this is found in the tension engendered at once both by that promise and by its inevitable disappointment. "The expensive car really brings beautiful women; the cigarette really takes one to the old West." 56

It is commercial advertising-this is what Adorno was writing about-that engenders the magical thinking Durão restricts in his analysis to the helpless Brazilian who "really," as Durão says, believes in such promises. It is a Marlboro commercial, which we recognize even though such commercials have been banned for years in the moraline quest to discourage smoking. This vision of the West draws on the collective unconscious whether one lives in São Paulo or New York. It is a Zane Grey Western and a Karl May novel.

\footnotetext{
${ }^{52} \mathrm{I}$ discuss this in connection with Adorno in the first chapters of Babich, The Hallelujah Effect and see too, from a French phenomenological perspective, David Sherman's discussion of Adorno and phenomenology, Sartre and Adorno: The Dialectics of Subjectivity (Albany: State University of New York Press, 2007), pp. 13ff.

${ }^{53}$ Robert Hullot-Kentor, "The Exact Sense in Which the Culture Industry No Longer Exists." In Durão, ed. The Culture Industry Today (Cambridge Scholar's Publishing, 2010), pp. 5-22.

${ }^{54}$ Durão, "Report on a Frankfurt School Conference in Brazil," Rethinking Marxism, Vol. 20/No. 2 (April 2008): 321-331, here pp. 322-323. Here, p. 323. Durão cites precisely this point.

${ }^{55}$ Durão, “Adorno in Brazil," p. 19.

${ }^{56}$ Ibid.
} 
The problem is that the subject who takes this on faith is male (and as I argue in The Hallelujah Effect, women share the conventions of the same subject). That subject in Beverley Hills or in Cannes or out in the Hamptons or on Martha's Vineyard knows - and knows quite empirically - that the expensive car, let's give it a name for full mythic effect, a Porsche or a Bentley, does indeed, just as really or literally, just as truly as you please, 'bring' (to use Durão's cargo cult term), beautiful women-who either share the same subjectivity as the male subject or do not count as "subjects" at all, be it for Kurz, even for Adorno, certainly not for Marcuse (author, good God, of Eros and Civilization) as much as they are themselves a market item like cars or cigarettes.

Contra the traditional mechanisms of repressive desublimation characteristic of technological modernity, there, in all the parts of the world where we are said to know better, is that even after eschewing the very idea of the postmodern, as Umberto Eco once observed, we nonetheless use the same knit-together patchwork of sophisticated irony to complement ourselves on that same critical sophistication.

Distracted in this way, in all the ways that we are scattered in our consciousness to ourselves and to the world around us, we are nowhere near changing the world. If Vattimo and Zabala can remind us that we can challenge the possessions of those in possession, to the extent that "hermeneutics is a way of looking at Being as an inheritance that is never considered as ultimate data," ${ }^{27}$ they also point out that we are up against a heritage of illusion, a history of lies:

\section{Capitalism has always grown by considering, or forcing another to consider, as a "natural" possession what is inherited. The great dominating families are really the inheritors of the strongest pirates, thieves, and bandits, and they consider themselves entitled to command through a divine or natural law, when they are really only the result of a forgotten "violence." 58}

If communism is a politics now long disfavored, a ghostly presence, it is a spectre with powers mobilized against it, powers of several wars, fought again and again, across the globe. In addition there is the theoretical ossification of communism, that is the materialism mentioned above. The promise of weakened thought, as Vattimo and Zabala explain hermeneutics, "proposes an effective conception of existence for those who do not wish to be enslaved in and by a world of total organization." 59 What this means as they rightly argue is that it is time to start making sense of the world but not in the ways that make rational, scientific, sense in the standard received fashion. Neither by way of the resources of analytic philosophy nor indeed by way of media debates on politics as these appear in the newspapers or on network(ed) news programs, it is time to begin "to interpret the world." 60

\footnotetext{
${ }^{57}$ Vattimo and Zabala, Hermeneutic Communism, p. 93.

${ }^{58}$ Ibid., p. 93.

${ }^{59}$ Ibid., p. 139.

${ }^{60}$ Ibid., p. 140.
} 